\title{
Regulatory Defect of Glycolysis in Human Lipoma
}

\author{
J. N. C. ATKINSON, \\ D. J. GALTON, \\ C. GILBERT
}

British Medical fournal, 1974, 1, 101-102

Lipolysis. - Tissue (50-150 mg) was preincubated for $30 \mathrm{~min}$ in Earle's bicarbonate buffer ( $\mathrm{pH} 7.4$ ) containing $1 \%$ crystalline serum albumin. The tissue was then transferred to $0.5 \mathrm{ml}$ of

\section{Summary}

A metabolic defect has been observed in extracts of lipomata in which citrate fails to inhibit the conversion of glucose-6-phosphate to glyceride-glycerol. Phosphofructokinase extracted from lipomata was less sensitive to inhibition by citrate than the enzyme of normal adipose tissue. However, maximal rates of lipogenesis (from glucose or palmitate) and lipolysis (stimulated with isoprenaline) in lipomata were similar to those of normal adipose tissue. This work suggests that loss of negative feedback control of regulatory enzymes may be an early feature in the development of neoplasia.

\section{Introduction}

The metabolic changes associated with neoplasia are very varied but include fundamental defects responsible for the altered growth properties of the tumour. The latter are best studied in minimal-deviation tumours because of their biochemical and morphological similarity to the cell of origin. Abnormalities in such tumours may therefore be closely linked to the development of neoplasia. A readily available example of such a tumour in man is the lipoma - a benign tumour of adipose tissue which accumulates neutral lipid at slightly greater rates and undergoes slightly faster rates of growth than surrounding tissue. Several factors could contribute to this increased deposition of lipid and include increased rates of lipogenesis from glucose or decreased mobilization of cellular triglycerides. The present study was undertaken to see if metabolic controls relating to lipid metabolism are deranged in lipomata; and we present evidence to suggest that these tumours have lost their ability to regulate glycolysis by feedback inhibition of phosphofructokinase (E.C.2.7.1.11) with citrate, which may allow glycolysis to operate maximally under all conditions for synthesis of glycerideglycerol.

\section{Materials and Methods}

Twenty-three lipomata were removed from various sites in 21 patients and transferred to the laboratory in $0.9 \%(\mathrm{w} / \mathrm{v})$ saline. In most cases adjacent adipose tissue was used as control. The following four sets of experiments were performed with the tissues.

Lipogenesis. - The conversion of glucose and palmitate into neutral lipid was measured in intact pieces of tissue $(5-50 \mathrm{mg}$ ) incubated in stoppered glass test-tubes in $0.5 \mathrm{ml}$ of Earle's bicarbonate buffer ( $\mathrm{pH} \mathrm{7.4)}$. Glucose and ${ }^{14} \mathrm{C}-\mathrm{U}$-glucose $(8 \mathrm{mM}$, $1 \mu \mathrm{Ci} / \mathrm{ml})$, palmitate and T-9, 10 -palmitate $(0.7 \mathrm{mM}, 1 \mu \mathrm{Ci} / \mathrm{ml})$, and crystalline serum albumin $(1 \% \mathrm{w} / \mathrm{v})$ were added to the buffer At the end of incubation tissue pieces were taken and precursor isotope was removed before extraction of neutral lipid into $10 \mathrm{ml}$ of scintillator (POPOP $0.05 \%$ and PPO $0.4 \%$ in toluene) for measurement of radioactivity, according to previously described methods (Galton et al., 1971).

Department of Biochemistry, University of Bristol

J. N. C. ATKINSON, M.B., PH.D., Research Assistant

Diabetes Research Laboratory, St. Bartholomew's Hospital, London EC1A 7BE

D. J. GALTON, M.D., M.R.C.P., Consultant Physician

C. GILBERT, B.SC., Research Assistant was measured enzymatically by the method of Garland and Randle (1962). For measurement of cyclic-AMP the tissue was preincubated for $30 \mathrm{~min}$ in Earle's bicarbonate buffer containing $1 \%$ bovine serum albumin and theophylline $(10 \mathrm{mM})$. The tissue was transferred to fresh buffer with or without isoprenaline $\left(10^{-5} \mathrm{M}\right)$ and after incubation for $5 \mathrm{~min}$ it was extracted into $0.2 \mathrm{ml}$ of cold $\mathrm{HCl}(6 \% \mathrm{v} / \mathrm{v})$. After neutralization with $\mathrm{KOH}$, cyclic-AMP was assayed by the competitive protein-binding method of Brown et al. (1971).

Glycolysis.- Soluble extracts of adipose tissue were prepared in a $\mathrm{KCl}: \mathrm{Mg}^{++}:$EDTA:mercaptoethanol buffer (150 mM:5 $\mathrm{mM}: 5 \mathrm{mM}: 10 \mathrm{mM}$ ) and the conversion of glycolytic intermediates (glucose-6-phosphate, fructose-6-phosphate, fructose $1: 6$ diphosphate) into glyceride-glycerol were measured by following the incorporation of tracer ${ }^{14} \mathrm{C}$-palmitate into neutral lipid, according to previously described methods (Galton and Wilson, 1970). Citrate when present was at a final concentration of 10 mM., which is about 10 times the concentration found in rat adipose tissue.

Phosphofructokinase Assays.-Adipose tissue or lipoma were homogenized in a buffer containing tris- $\mathrm{HCl}(50 \mathrm{mM}, \mathrm{pH} 8.0)$, EDTA (2 $\mathrm{mM})$, and $\mathrm{NaF}(4 \mathrm{mM})$. Fluoride stabilized the enzyme which otherwise lost its activity after 12-24 hours. The enzyme was assayed in crude suprenatants by converting fructose diphosphate into glycerol phosphate and recording the disappearance of $\mathrm{NADH}$ at $340 \mathrm{~nm}$ in a cuvette $(1 \mathrm{~cm}$ light path) at $25^{\circ} \mathrm{C}$. Each cuvette contained tris- $\mathrm{HCl}$ buffer ( $\mathrm{pH}$ 7.4, $125 \mathrm{mM}), \mathrm{KCl}(150 \mathrm{mM}), \mathrm{MgCl}_{2}$ (12.5 mM), NADH (0.1 mM), aldolase (0.9 units), triosephosphate isomerase (12 units), and glycerophosphate dehydrogenase (1 unit). Fructose-6-phosphate and adenosine triphosphate (ATP) were added in various concentrations to make a total volume of $2.5 \mathrm{ml}$. Ammonium sulphate was maintained at $2.0 \mathrm{mM}$ because no activity was found in the absence of activator ions. Assays were started by adding fructose-6-phosphate, and after equilibration, rates were linear for at least $5 \mathrm{~min}$ (Atkinson, 1973).

\section{Results}

The rates of conversion of glucose and palmitate to neutral lipid in lipoma and adipose tissue are shown in the table. A time course was run for each substrate but only one-hour values are reported since no significant differences were noted. Likewise, the maximal rates of glycerol release, and rises in tissue levels of cyclic-AMP after stimulation with isoprenaline $\left(10^{-5} \mathrm{M}\right)$ were similar in lipoma and control tissue.

Glucose-6-phosphate (6 $\mathrm{mM})$ was actively incorporated into glyceride-glycerol by soluble extracts of adipose tissue (fig. 1) and this was inhibited by the addition of citrate $(10 \mathrm{mM})$. No inhibition by citrate was observed if fructose diphosphate $(6 \mathrm{mM})$ was used instead of glucose-6-phosphate, suggesting that citrate is inhibiting the enzyme phosphofructokinase. Extracts of lipoma also incorporated glucose-6-phosphate into glyceride-glycerol, but this could not be inhibited by the addition of citrate (fig. 1).

Phosphofructokinase was extracted from four lipoma for comparison with adipose tissue. Measurements of the catalytic activity and the kinetics of inhibition by ATP of the tumour enzyme were similar to those for normal adipose tissue. However, 
Metabolic Pathways in Lipoma. Results are expressed as Mean \pm S.E. of Mean Numbers of Tests are given in Parentheses)

\begin{tabular}{|c|c|c|c|c|c|c|}
\hline & & & \multicolumn{2}{|c|}{ Lipogenesis from: } & \multicolumn{2}{|c|}{ Lipolysis with Isoprenaline, Increments in: } \\
\hline & & & Glucose $(\mu \mathrm{mol} / \mathrm{g} / \mathrm{hr})$. & Palmitate $(\mu \mathrm{mol} / \mathrm{g} / \mathrm{hr}$.) & Cyclic-AMP (pmol/mg/5 min.) & Glycerol $(\mu \mathrm{mol} / \mathrm{g} / \mathrm{hr})$. \\
\hline $\begin{array}{l}\text { Lipoma } \\
\text { Adipose tissue }\end{array}$ & $\because$ & $\begin{array}{ll} & \cdots\end{array}$ & $\begin{array}{l}0.68 \pm 0.08(6) \\
0.56 \pm 0.10(6)\end{array}$ & $\begin{array}{l}0.88 \pm 0.14(6) \\
0.89 \pm 0.16(6)\end{array}$ & $\begin{array}{l}2.28 \pm 0.27(10) \\
3.62 \pm 0.70(7)\end{array}$ & $\begin{array}{l}0.44 \pm 0.05(6) \\
0.36 \pm 0.10(4)\end{array}$ \\
\hline
\end{tabular}
Adipose tissue or lipoma $(5-150 \mathrm{mg})$ were incubated in Earle's bicarbonate buffer for varying periods of time and assays were performed as described in Methods. Differences
between lipoma and adipose tissue were not statistically significant when tested by Student's $t$ test.

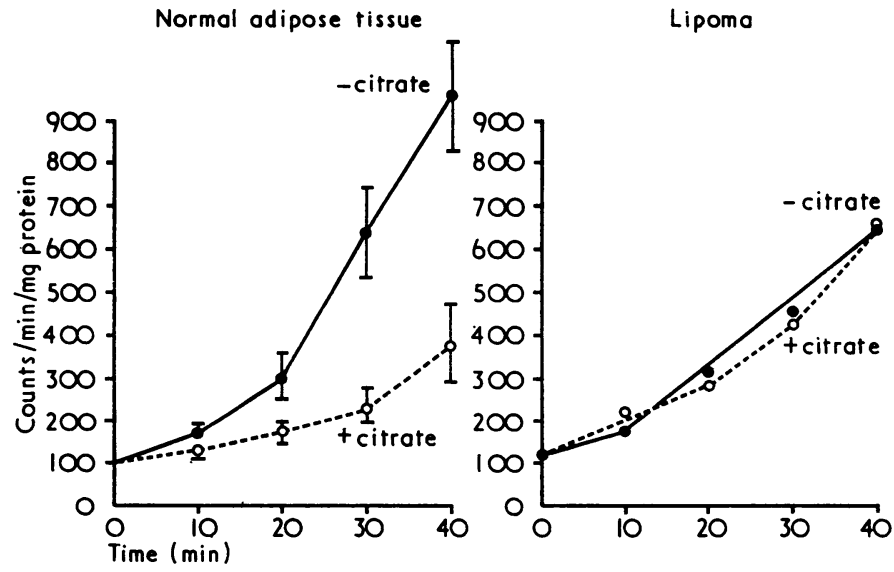

FIG. 1-Effect of citrate on conversion of glucose-6-phosphate to glycerideglycerol. Extracts of tissue $(0.1 \mathrm{ml})$ were incubated in test-tubes with $\mathrm{KCl}$ phosphate buffer (pH 7.4) $50 \mathrm{mM}$; coenzyme A $0.12 \mathrm{mM} ; \mathrm{MgCl}_{2} 2.3 \mathrm{mM}$; ATP $1.5 \mathrm{mM}$; and $\left(1-^{14} \mathrm{C}\right)$-palmitate $0.15 \mu \mathrm{Ci}$ as tracer. Rate of incorporation of ${ }^{14} \mathrm{C}$-palmitate into glyceride was followed by scintillation spectrometry. Points are means of seven lipomata and six control tissues with S.E. of mean enclosed between bars.

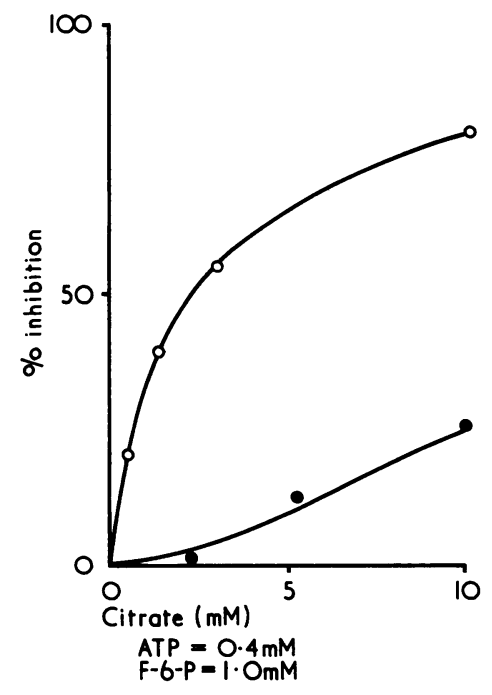

FIG. 2-Effect of citrate on phosphofructokinase from lipoma and adipose tissue. Phosphofructokinase was measured in extracts of tissue according to Methods (ATP $0.4 \mathrm{mM}$; fructose-6-phosphate $1.0 \mathrm{mM}$ ) in presence of increasing concentrations of citrate. Points are means of four lipomata from four patients with adjacent adipose tissue as control. $\mathrm{O}-\mathrm{O}=$ Adipose tissue. = Lipomata.

inhibition by citrate was grossly impaired over a range of ATP and fructose-6-phosphate concentrations in the four lipomata. An inhibition curve using ATP $(0.4 \mathrm{mM})$ and fructose-6-phosphate $(1 \mathrm{mM})$ is given in fig. 2 and shows the decreased sensitivity of lipoma phosphofructokinase to inhibition by concentrations of citrate up to $10 \mathrm{mM}$.

\section{Discussion}

It is clear that tumour cells have altered control mechanisms which lead to increased rates of growth, though the molecular abnormalities responsible for this remain obscure. It is possible that this could be related to structural changes resulting in abnormalities at the regulatory binding sites of allosteric enzymes which are involved in metabolic pathways responsible for cell growth and division. If so, such defects may also occur on enzymes of other metabolic paths; and Siperstein and Fagan (1964) showed that the negative feedback control of cholesterol biosynthesis was lost in some varieties of rat hepatomas. They attributed this to a structural defect in the enzyme hydroxymethyl glutaryl-CoA reductase, so that it was no longer sensitive to feedback inhibition by cholesterol (Siperstein et al., 1966). This suggests that tumour enzymes other than those involved in cell division may be structurally modified so that they no longer respond to environmental controls.

In the human lipoma a similar situation seems to arise. Though maximal rates of lipolysis and lipogenesis are alike in tumour and control tissue, the metabolic segment from glucose-6phosphate to glyceride-glycerol appears to be insensitive to feedback inhibition by citrate in lipoma. Furthermore, phosphofructokinase extracted from lipoma showed a greatly reduced sensitivity to inhibition by citrate over a range of ATP and fructose-6-phosphate concentrations. Phosphofructokinase in human adipose tissue is a complex enzyme with multiple regulatory sites. For example, at $\mathrm{pH} 7.4$ or lower, ATP at low concentrations acts as a substrate for the enzyme, but above levels of $0.1 \mathrm{mM}$ it becomes an inhibitor. The kinetics of ATP inhibition of lipoma phosphofructokinase are the same as those for adipose tissue; and the specific activity of the tumour enzyme is also within the range of normal adipose tissue, at 0.033 units $/ \mathrm{mg}$ protein (Atkinson, 1973). However, the tumour enzyme appears to have a defect in the regulatory sites involved in the inhibition by citrate. This would indicate that there has been a change in enzyme structure (perhaps as a variation in amino-acid sequence) at the regulatory sites for combination with citrate, without affecting the catalytic site. The consequences of this may be that the tumour enzyme operates under conditions of maximal stimulation, being virtually unmodulated with respect to inhibition by citrate. This in turn may be linked to the increased deposition of lipid found in these tumours.

Requests for reprints should be addressed to Dr. D. J. Galton, Departments of Medicine (Research), St. Bartholomew's Hospital, London EC1A 7BE.

We are most grateful to Professor P. J. Randle, Professor Sir Eric Scowen, and Professor J. Landon for encouragement in this work. The work was partly supported by the Medical Research Council and the British Diabetic Association, with whom J.N.C.A. held a Laurence Fellowship.

\section{References}

Atkinson, J. N. C. (1973). Ph.D. Thesis, University of Bristol.
Brown, B. L., Albano, J. D. M., Ekins, R. P., and Sgherzi, A. M. (1971). Biochemical fournal, 121, 561.

Galton, D. J., and Wilson, J. P. D. (1970). Clinical Science, 38, 649.

Galton, D. J., Wilson, J. P. D., and Kissebah, A. H. (1971). European fournal of Clinical Investigation, 1, 399.

Garland, P. B., and Randle, P. J. (1962). Nature, 196, 987.

Siperstein, M. D., and Fagan, V. M. (1964), Cancer Research, 24, 1108.

Siperstein, M. D., Fagan, V. M., and Morris, H. P. (1966). Cancer Research, 26, 7. 